\title{
ADDITIONAL CURLEW SANDPIPER RECORDS FROM MANITOBA
}

R.D. MCRAE, Box 98, Brighton, Ontario, KOK $1 \mathrm{HO}$ and R.J. BROOKS, University of Guelph, Department of Zoology, Guelph, Ontario. N1G 2W1

Holohan reported sighting a Curlew Sandpiper at Oak Hammock Marsh 1 June 1981 which was supposedly the first Manitoba record (1983. Curlew Sandpiper in Manitoba. Blue Jay 41(4):205-207). We provide details of two additional records from Churchill which are, chronologically, the first and third records for the province.

On 29 May 1973, Brooks and M. Skeel found and photographed a Curlew Sandpiper at the ponds near the grain elevator. They observed the bird for 30 minutes while it foraged at the south edge of the southern-most pond. Copies of the photographs have been deposited in the Royal Ontario Museum and the National Museum of Natural Sciences. The bird was mottled in overall appearance and was a dull shade of red on the breast and head. If it was in full breeding plumage, it was likely a female.

The most recent record involved a bird seen by McRae and P.H. Sinclair 10 June 1983 as it did a quick "fly-by" of the Akudlik Marsh, $5 \mathrm{~km}$ east of Churchill. Several hours later, a group from the
Saskatchewan Natural History Society, led by Stan Shadick, saw the bird as it repeated another "fly-by." These were the only two sightings of this bird. This bird was almost certainly a male as its throat, neck and breast were bright red, similar to the breast colour of a female Red Phalarope, and showed no mottling or faint areas of colour. A detailed description of this individual is on file at the Manitoba Museum of Man and Nature.

A quick survey of the seasonal summaries published in American Birds shows that Curlew Sandpiper sightings in inland North America have increased dramatically in the past two decades. Although these are the only three records for the province so far, it seems likely that other individuals will be found periodically, especially if the amount of birdwatching along the Hudson Bay coast is increased.

We would like to thank Clive E. Goodwin, Stewart Holohan and J.E.H. Mason for their help in locating information for this note. 